\title{
EVALUATION OF FINANCIAL DISTRESS COSTS OF INNOVATIVE COMPANIES
}

\author{
E. Y. MAKEEVA* \\ National Research University Higher School of Economics, Russia ${ }^{\text {a }}$ \\ M. O. KHUGAEVA \\ Financial University under the Government of the Russian Federation, Russia ${ }^{\mathrm{b}}$
}

\begin{abstract}
Over the last few decades investments in research and development (R\&D) projects have risen significantly. Many experts have found a positive relationship between R\&D expenses and a company's value. However, investments in innovations are characterized by a high level of uncertainty. Often innovations generate income only in long run. These factors increase the probability of firms' financial distress considerably. Thus, the aim of the present paper is to evaluate financial distress costs at companies that invest in research and development projects. The study covers 389 innovative firms over the period from 2006 to 2015 . The analysis is based on a direct and indirect costs evaluation. The first are estimated through panel logistic regression. Indirect costs are calculated as unexpected losses or profits relative to industry indicators. The paper confirms the existence of relation between R\&D expenses and financial instability. The results of the research show that the total financial distress costs of innovative companies amount to $7.95 \%$ of total assets or $11.78 \%$ of the value of a company on average.
\end{abstract}

Keywords: financial distress costs, bankruptcy, innovative companies, panel logistic regression.

JEL: G32, G33.

One of the most important factors determining a firm's profitable growth is scientific and technological progress. Innovations are vitally important for companies to compete with one another. Global statistics shows that a huge amount of investments are focused on research and development projects in different sectors of the economy such as software and programming, biotechnological products, capital goods, beverages,

\footnotetext{
* Corresponding author: len-makeeva@yandex.ru

a Postal Address: 20 Myasnitskaya ul., National Research University Higher School of Economics, Moscow, 101000, Russia.

${ }^{\mathrm{b}}$ Postal Address: 49 Leningradsky prosp., Financial University under Government of Russian Federation, Moscow, 125993, Russia.

(c) E.Y.Makeeva, M.O. Khugaeva, 2018

https://doi.org/10.21638/11701/spbu18.2018.102
} 
accessories, restaurants, retail, hotels and motels, and so on.

However, R\&D investments are characterized by high uncertainty, so not every company can afford such risky investments. Most small and medium enterprises (SMEs) are examples of the latter type. Besides external uncontrollable factors such as crises, disasters, political instability, and armed conflicts, each firm has its own internal problems. Taken together this can lead to financial distress or even failure of a firm, and each additional risky asset can increase the probability of insolvency.

Thus, the relevance of the present paper is that each company has to find the optimal tradeoff between investments in innovations and risk of financial distress. The solution to this problem can improve a company's efficiency and lead to its growth. And vice versa, an unsuccessful selection can result even in the failure of a firm.

The purpose of the present paper is to evaluate financial distress costs of innovative companies. The subject of the investigation is financial distress costs. Our study focuses on companies that spent at least $\$ 200$ million on research and development in 2015. Data are collected from Bloomberg and the financial reports of companies. The novelty of the present paper is in suggested model for direct and indirect cost evaluation of innovative companies.

\section{Literature Review}

Academic papers define financial distress as the condition experienced by a company that cannot pay its obligations to finance its debt. Analysts differentiate it from bankruptcy, explaining this by the fact that bankruptcy is one of the outcomes of insolvency. However, the latest financial crisis showed that a corporation can go bankrupt very unexpectedly. That is why it is necessary to be on the lookout even for "healthy" companies and observe their financial distress costs in order to take action before their failure.
Empirical studies outline two types of financial distress costs: direct and indirect. Direct costs include different administrative costs connected with the bankruptcy, reorganization, liquidation process, or other bankruptcy costs. Indirect costs are defined as alternative costs or missed opportunities.

The paper [Warner, 1977] was one of the first papers devoted to financial distress costs evaluation. The author examines direct costs at 11 railroad companies in the US in 1933-1955 using the following method. He takes expenditures connected with the bankruptcy process and divides this figure by the amount of a firm's total market value. However, the important assumption was that a company's value is equal to equity and debt issued in the seven years preceding the bankruptcy. The results of Warner's research showed that direct financial costs are equal to $1.0-5.3 \%$ of firm's value on average (depending on the chosen base year). Therefore, it was concluded that these costs do not influence financial decisions as they are much smaller than tax benefits.

The studies followed after [Warner, 1977] did not yield significant results for capital structure decisions. The question arises: if distress costs are not important, then why do firms not use debt financing alone? Thus the experts decided to find the indirect costs of financial distress. The first expert who tried to calculate them was E. Altman. In [Altman, 1984] he tried to find the optimal capital structure by comparing bankruptcy costs with the benefits provided by financial leverage and, in the case when the present value of insolvency is higher than tax gains, the company has to decrease its debt to equity ratio. The results of Altman's analysis show that bankruptcy costs matter: in the three years preceding bankruptcy, total bankruptcy costs were equal to $12.4-16.7 \%$ of the firm's value on average. Also, the author finds that present value of bankruptcy costs is higher than the present value of tax benefits at most of studied firms and, consequently, the firms' debt level is much higher than their optimal one. 
The paper [Thorburn, 2000] examined 263 Swedish bankrupt firms. The author estimates direct bankruptcy costs (such as lawyer, consulting, \& administrative costs) and finds that these costs represent $6.4 \%$ of pre-filing assets on average, and 19.1\% for bankruptcy auctions. The results are significant, although the author only examines the direct costs of financial distress. Another view on distress costs was put forward by [Opler, Titman, 1994]. They tried to analyze the link between insolvency and corporate performance in distressed industries rather than individual distressed companies. The authors compared whether highly leveraged companies lose more operating profit than more conservative ones. Unfortunately, Opler and Titman did not evaluate the costs of financial distress, but they did come to the conclusion that connection between debt ratio and performance is stronger for companies with huge $R \& D$ investments and in the case of more concentrated industries.

The idea of financial distress costs analysis, without any reference to economic costs, was developed in the paper [Andrade, Kaplan, 1998]. They analyze 31 financially distressed, highly leveraged transactions (HLT) and find that the net costs of financial distress amount about $10-20 \%$ of firm's value. These results explain why firms behave themselves quite conservatively.

Although the aforementioned papers are rather old, there are many studies that use the methodologies proposed there. For example, the indirect costs calculation approach of Altman was recently repeated by [Kwansa, Cho, 1995; Pham, Chow, 1989; Bhabra, Yao, 2011; Bulot, Salamudin, Abdoh, 2014] and others.

In [Kwansa, Cho, 1995] authors covered bankrupt restaurant firms' indirect costs and found that they should be taken into account when making financial decisions (on average, $7 \%$ of firm's value). In their turn, Pham \& Chow (1989) analyzed bankrupt Australian companies in 1978-1983. The authors came to the conclusion that total financial distress costs were equal to 15.9-22.4\% of a company's value. This fact also supports the hypothesis that distress costs matter. Later, in [Bhabra, Yao, 2011], the US bankrupt firms in 1997-2004 were examined. It was found that the costs of financial distress divided by a company's value amounted $6.09 \%, 9.71 \%$ and $17.43 \%$ relative to the year prior to bankruptcy. For the developing markets [Wijantini, 2007] covered Indonesian financially distressed companies in the period from 1997 to 2002. The found mean value of indirect costs was equal to $3-11 \%$ of total sales. Recently, [Bulot, Salamudin, Abdoh, 2014] tried to estimate indirect costs of financial distress in the trading and services sector in Malaysia. The analysis finds that indirect costs are significant and amounted $3.1-21.39 \%$ of firms' value. Malaysian firms were also examined in [Bulot, Salamudin, Aziz, 2017]. The analysis of 190 financially distressed companies in 2001-2011 revealed that indirect distress costs are equal to $21.6 \%$ on average.

Another method of measuring indirect costs of financial distress was used in [Hortaçsu et al., 2013]. The authors analyze all public automobile companies in the period between 1985 and 2010. They examine indirect financial costs using credit default swap spreads and find that marginal indirect costs are equal to $2-39 \%$ of firm's value. The researchers paid attention to Ford and General Motors, and compared their distress costs to tax benefits. The analysis showed that indirect costs in some years exceeded tax benefits.

Many papers devoted to direct financial costs are based on another Altman study, the Z-score model. The article was written in 1968 , but it remains very popular still. The aim of the paper was to develop a model that can predict a firm's bankruptcy with the help of financial and economic ratios [Altman, 1968].

The other method for calculating direct costs was used in [Mansi, Maxwell, Zhang, 2012]. Their study covers 120608 monthly observations on 1752 companies during the 
period from 1980 to 2006. The researchers made an effort to determine bankruptcy probability according to firms' bond ratings. The results showed average figures for AA, $\mathrm{A}, \mathrm{BBB}, \mathrm{BB}$ and $\mathrm{B}$ rated companies being equal to $0.206,0.255,0.353,0.433$ and 0.535 , respectively.

In [Zhang, 2015] the author also uses Z-score. He examines whether there is any connection between R\&D investments and a company's distress risk measured by Altman's Z-score. The results show a positive relationship, which is especially high during economic downturns [Zhang, 2015]. The author introduces and estimates four models with four R\&D indicators: R\&D expenses scaled by total assets, sales, number of employees, and R\&D capital divided by total assets. The present paper refers to Zhang's R\&D index evaluation for further investigation of distress risk costs in the innovative sector.

Findings of all covered studies are briefly described in Table 1.

In order to estimate direct and indirect costs, analysts used different methodologies. Altman in his paper of 1968 estimated direct financial distress costs through bankruptcy. He used multiple discriminant analysis to determine variables that influence the likelihood of insolvency. This investigation has disadvantages: it involves a firm's characteristics, but does not consider countryspecific indicators. That is why it should not be used for developing countries. Besides, it is not very good for studying longterm forecasts.

After Altman's paper, multiple discriminant analysis became very popular for bankruptcy prediction. Many modifications of the Z-score equation were developed with different independent variables; their number amounted to 2-47. However, multiple discriminant analysis has a huge drawback: there is no opportunity to predict the probability of bankruptcy for firms that are in the "grey area".

Another method was suggested in [Ohlson, 1980]. He tried to estimate bankruptcy prob- ability through a logistic regression model. The sample consisted of 105 bankrupt companies and 2058 non-bankrupt firms during the period between 1970 and 1976. Ohlson tested nine variables and only four of the characteristics showed significant results: size, financial structure, performance, and current liability.

There are many papers that based their research on Ohlson's methodology. One of them is [Ho et al., 2013]. The authors analyzed 122 North American public companies in the period from 1990 to 2009. The sample includes 12 bankrupt firms. Two models were proposed. The first one includes nine variables according to Ohlson's methodology and the second one includes nine factors, and also real GDP growth and the real interest rate of two-year Treasury bonds as macroeconomic proxies. As expected, the extended model predicts bankruptcy better than the original.

Recent papers also show a preference for binary choice models, and the results give a very high level of prediction. For example, [Jones, Hensher, 2004] analyzed 3032 firm-year observations in the period between 1996 and 2000. The authors used a mixed logit model and came to the conclusion that the model has a forecasting accuracy of $99.16 \%$ on the pooled data. In [Laitinen, Suvas, 2016] authors gathered a large sample of 1255768 non-bankrupt and 22594 bankrupt firm-year observations from 26 countries during 2007-2010. The authors examined the influence of Hofstede's cultural characteristics on financial distress prediction and found that some of them demonstrate a significant impact.

Russian researchers also prefer to use this methodology. In [Zhdanov, Afanasyeva, 2011] the aviation industry was examined. The authors analyze 20 non-bankrupt and 20 bankrupt companies in 2001-2010. Forty variables are divided into four categories: profitability, financial sustainability, business activity, and liquidity. The results show that the model accuracy for the Russian aviation industry amounts $75 \%$.

RMJ 16 (1): 37-62 (2018) 
Summary of financial distress costs' studies

\begin{tabular}{|c|c|c|c|}
\hline Author & Data & Period & Results \\
\hline \multicolumn{4}{|c|}{ Direct costs } \\
\hline Warner (1977) & 11 US railroad firms & $1933-1955$ & $1.0-5.3 \%$ of firm's value on average \\
\hline Altman (1984) & $\begin{array}{l}18 \text { US firms: } 11 \text { retail- } \\
\text { ers, } 7 \text { other industrial } \\
\text { firms }\end{array}$ & $1974-1978$ & $8.1-10.5 \%$ of firm's value \\
\hline $\begin{array}{l}\text { Pham, Chow } \\
\text { (1989) }\end{array}$ & 55 Australian firms & $\begin{array}{l}\text { September } \\
1978-\text { May } \\
1983\end{array}$ & $\begin{array}{l}\text { On average } 2.5 \% \text { and } 3.6 \% \text { of firm value at } \\
\text { the year before bankruptcy and in the year } \\
\text { when bankruptcy occurred }\end{array}$ \\
\hline Weiss (1990) & 37 US firms & $\begin{array}{l}\text { November } \\
1979-\text { Decem- } \\
\text { ber } 1986\end{array}$ & $\begin{array}{l}\text { On average from } 1 \% \text { to } 6.6 \% \text { of market capi- } \\
\text { talization of shares }\end{array}$ \\
\hline $\begin{array}{l}\text { Andrade, Kaplan } \\
\text { (1998) }\end{array}$ & $\begin{array}{l}31 \text { financially distressed } \\
\text { firms with highly lever- } \\
\text { aged transactions }\end{array}$ & $1980-1989$ & $10-20 \%$ of firm's value \\
\hline Thorburn (2000) & 263 Swedish firms & $1988-1991$ & $\begin{array}{l}6.4 \% \text { of pre-filing assets on average, and } \\
19.1 \% \text { for bankruptcy auctions }\end{array}$ \\
\hline $\begin{array}{l}\text { LoPucki, } \\
\text { Doherty (2004) }\end{array}$ & 48 US firms & $1998-2002$ & $1.4 \%$ of firm's assets \\
\hline $\begin{array}{l}\text { Bris, Welch, } \\
\text { Zhu (2006) }\end{array}$ & $\begin{array}{l}286 \text { firms in Arizona } \\
\text { and New York }\end{array}$ & $1995-2001$ & $\begin{array}{l}8.1 \% \text { of firm's pre-bankruptcy assets on } \\
\text { average after liquidation; } 1.6 \% \text { of firm's } \\
\text { pre-bankruptcy assets on average after reor- } \\
\text { ganization }\end{array}$ \\
\hline $\begin{array}{l}\text { Mansi, Maxwell, } \\
\text { Zhang (2012) }\end{array}$ & 1752 companies & $1980-2006$ & $\begin{array}{l}\text { Bankruptcy probability for } \mathrm{AA}, \mathrm{A}, \mathrm{BBB}, \\
\mathrm{BB} \text {, and } \mathrm{B} \text { bonds on average is } 0.206,0.255 \text {, } \\
0.353,0.433 \text {, and } 0.535 \text {, respectively }\end{array}$ \\
\hline $\begin{array}{l}\text { Charalambakis, } \\
\text { Garrett (2016) }\end{array}$ & $\begin{array}{l}\text { UK and Indian compa- } \\
\text { nies }\end{array}$ & $1980-2011$ & $\begin{array}{l}\text { Expected default frequency for UK market is } \\
\text { equal to } 1 \% \text {, and for Indian firms }-2 \%\end{array}$ \\
\hline \multicolumn{4}{|c|}{ Indirect costs } \\
\hline Altman (1984) & $\begin{array}{l}18 \text { US firms: } 11 \text { retail- } \\
\text { ers, } 7 \text { other industrial } \\
\text { firms }\end{array}$ & $1974-1978$ & $4.3-6.2 \%$ of firm's value \\
\hline $\begin{array}{l}\text { Pham, Chow } \\
\text { (1989) }\end{array}$ & 55 Australian firms & $\begin{array}{l}\text { September } \\
1978-\text { May } \\
1983\end{array}$ & $\begin{array}{l}\text { On average } 13.4 \% \text { and } 18.7 \% \text { of firm value } \\
\text { at the year before bankruptcy and in the } \\
\text { year when bankruptcy occurred }\end{array}$ \\
\hline $\begin{array}{l}\text { Kwansa, Cho } \\
(1995)\end{array}$ & US restaurant firms & $1980-1992$ & $7 \%$ of firm's value on average \\
\hline Wijantini (2007) & 28 Indonesian firms & $1997-2002$ & $3-11 \%$ of total sales on average \\
\hline $\begin{array}{l}\text { Bhabra, Yao } \\
(2011)\end{array}$ & $\begin{array}{l}62 \text { bankrupt firms in } \\
\text { USA }\end{array}$ & $1997-2004$ & $\begin{array}{l}2 \%, 6.2 \% \text { and } 14.9 \% \text { of firm value in the } \\
\text { year prior to bankruptcy }\end{array}$ \\
\hline $\begin{array}{l}\text { Hortaçsu et al. } \\
(2013)\end{array}$ & $\begin{array}{l}\text { Automobile manufac- } \\
\text { turers in the US }\end{array}$ & $1985-2010$ & $2-39 \%$ of firm's value \\
\hline $\begin{array}{l}\text { Bulot, } \\
\text { Salamudin, } \\
\text { Abdoh (2014) }\end{array}$ & $\begin{array}{l}48 \text { Malaysian listed } \\
\text { companies from trad- } \\
\text { ing and services sector }\end{array}$ & $\begin{array}{l}15 \text { February } \\
2001-31 \text { De- } \\
\text { cember } 2011\end{array}$ & $3.1-21.39 \%$ of firms' value \\
\hline Bulot et al. (2017) & 190 Malaysian firms & $2001-2011$ & $21.6 \%$ of total sales on average \\
\hline
\end{tabular}


Table 2

Advantages and disadvantages of different methods for evaluating the probability of bankruptcy

\begin{tabular}{|c|c|c|}
\hline Method & Advantages & Disadvantages \\
\hline $\begin{array}{l}\text { Multiple } \\
\text { Discriminant } \\
\text { Analysis }\end{array}$ & $\begin{array}{l}\text { Simple calculation. } \\
\text { Use of several accounting indicators simultane- } \\
\quad \text { ously }\end{array}$ & $\begin{array}{l}\text { Assumptions of normality. } \\
\text { "Grey zone". } \\
\text { Complicated interpretation of results }\end{array}$ \\
\hline $\begin{array}{l}\text { Binary } \\
\text { Model }\end{array}$ & $\begin{array}{l}\text { High level of accuracy. } \\
\text { Simple calculation. } \\
\text { Ability to take into account industry specific } \\
\text { factors }\end{array}$ & $\begin{array}{l}\text { Does not work well with a large number } \\
\text { of categorical variables. } \\
\text { Multicollinearity can lead to overestima- } \\
\text { tion of results }\end{array}$ \\
\hline $\begin{array}{l}\text { Neural } \\
\text { Networks }\end{array}$ & $\begin{array}{l}\text { Does not take non-normality or correlation } \\
\text { between variables into account. } \\
\text { Works with incomplete samples or those that } \\
\text { are not clearly defined }\end{array}$ & $\begin{array}{l}\text { Sophisticated methodology/code writing. } \\
\text { Too sensitive for chosen sample. } \\
\text { Complicated interpretation of results }\end{array}$ \\
\hline
\end{tabular}

Another interesting paper is [Fedorova, Gilenko, Dovzhenko, 2013], which studied the Russian manufacturing industry. The sample involves 3001 non-bankrupt and 504 bankrupt firms during the period from 2007 to 2011. Both logit-regression method and probit approach were used. However, the results show that the logit approach is better suited. The accuracy of the model was estimated using two methods and demonstrated a predictive accuracy of $87.14 \%$ and $84.7 \%$, which proves the high predictive power of the model.

Many research studies devoted to bankruptcy probability prediction suggested another methodology, i.e., the neural networks approach. This approach has advantages over the others since it does not take non-normality or correlation between variables into account; it does not have the same limitations possessed by a multiple discriminant analysis or binary model when a sample is incomplete or not clearly defined. That is why some authors think that this technique can predict bankruptcy better then statistical methodology. However, previous research does not always prove it. For example, [Chen et al., 2006] examined 940 non-bankrupt and 89 bankrupt Chinese firms between 1990 and 2003. The authors used four models to predict bankruptcy: linear discriminant analysis, logistic regression, decision trees, and a neural network. In order to find which model works best, the authors estimated the total costs of misclassification, and the logistic regression and neural networks yielded the poorest results.

The paper [Makeeva, Bakurova, 2012] presents the prediction of bankruptcy at European oil \& gas companies in the period from 2000 to 2010. The authors used two approaches: logistic regression and neural network. They came to the conclusion that logistic regression does not work as well as neural networks since the accuracy of models is equal to $76 \%$ and $98 \%$, respectively. Although the second method predicts better, [Makeeva, Bakurova, 2012] emphasized that using this technique greatly depends on the chosen sample, which can lead to biased results.

Unfortunately, there is no perfect method that suits every research study. So, in order to put together the pros and cons of the most popular approaches we place Table 2.

Empirical studies do not have many techniques for evaluating indirect financial costs. Probably the oldest approach was suggested in [Altman, 1984]. He estimated indirect costs as the profit losses/gains relative to industrial figures. It is important to mention that this method was used by most researchers who tried to evaluate indirect distress costs to present. That is why the methodology of the present paper will follow it, too. A detailed, step-by step explanation will be provided later. 


\section{Hypotheses}

Against this presented background of theoretical and empirical studies we can formulate the set of hypotheses.

Performance characteristics of a firm. The nine financial explanatory variables are taken from Ohlson's paper. The authors decided to forecast their influence on the probability of bankruptcy in accordance with the original paper [Ohlson, 1980]. Leverage is estimated as the total debt to market capitalization. The higher the debt, the higher are the interest expenses that negatively influence the interest coverage ratio. Dependent variable is a dummy variable equal to 1 if interest coverage is less than 1 and 0 otherwise. The influence of current liabilities to current assets and cash flow from operating activity to total debt has the same logic, so sign of these variables should be positive and negative, respectively. Working capital scaled by total assets is expected to be negative, as the numerator of the ratio is estimated as current assets minus current liabilities. Thus, the higher the working capital, the lower are the interest expenses, and the higher is the interest coverage ratio, so the dummy is not equal to 1 .

Variables that include net income have an impact on earnings before interest, taxes, depreciation and amortization (EBITDA), which is the numerator of the interest coverage ratio. Therefore, the return on assets and changes in net income have a positive effect on the interest coverage ratio, but a negative impact on the dependent dummy. The dummy for net income, if it was negative over the last two years is equal to 1 , and 0 otherwise. It should have a positive impact as if it is equal to 1 , then interest coverage is lower than 0 , and the dependent dummy is equal to 1 . The size of company is presented by a natural logarithm of total assets. Logically, the larger the company is, the lower is the likelihood of bankruptcy.

The dummy for the total debt to total assets ratio is included in the equation as a correction for the companies with a nega- tive equity value. Ohlson suggests that the coefficient may have different signs, so its influence is indeterminate.

It was suggested that direct financial costs are estimated as the probability of bankruptcy multiplied by sales, which means that the probability of bankruptcy has direct impact on these costs. So, if the listed factors are significant in the likelihood of bankruptcy, they play the same role in an evaluation of direct financial costs. Thus, the following hypotheses are posited:

Hypothesis 1. Leverage has positive influence on the probability of bankruptcy.

Hypothesis 2. The current liabilities to current assets ratio has a positive influence on bankruptcy probability.

Hypothesis 3. The dummy for net income has a positive impact on the probability of bankruptcy.

Hypothesis 4. The size of a company negatively influences the likelihood of bankruptcy.

Hypothesis 5. Working capital scaled by total assets has negative influence on bankruptcy probability.

Hypothesis 6. Return on assets has negative impact on the probability of bankruptcy.

Hypothesis 7. Cash flow from operating activity to total debt has a negative influence on bankruptcy probability.

Hypothesis 8. Net income growth has negative impact on the probability of bankruptcy.

Market characteristics of a firm. Here book to market value of total assets and stock return volatility are analyzed. According to [Zhang, 2015], they have a positive impact upon the probability of distress.

Hypothesis 9. The higher the book to market value of total assets, the higher are the direct financial distress costs.

Hypothesis 10. The higher the stock return volatility, the higher are the direct financial distress costs.

Research \& development characteristics of a firm. R\&D expenses are very risky investments because of the uncertainty since only a portion of R\&D investments lead to 
successful outcomes. That is why previous empirical papers have found a positive relationship between R\&D expenses and financial distress.

Hypothesis 11. The higher the R\&D expenses, the higher are the direct financial distress costs.

\section{Data}

\section{Sample}

To evaluate financial distress costs of innovative companies, a sample comprised of 389 firms spending more than $\$ 200$ million a year on research and development in 2015 was gathered. Information about companies and industries was collected for the period from 2006 to 2015. Most data were taken from Bloomberg; the rest of indicators were taken from the annual reports of the companies themselves.

The sample presents firms from 25 countries: $37 \%$ of the most innovative companies are from the US, 19\% from Japan, and 10\% from China. The rest of the corporations are from Germany, South Korea, Switzerland, Japan, Great Britain, France, Finland, the Netherlands, Sweden, Ireland, Taiwan, Denmark, Italy, Israel, Belgium, Spain, Bermuda, Australia, Saudi Arabia Brazil, Russia, Canada, and India. The firms from both developed and emerging economies are represented in the sample. The data is in millions of US dollars, except stock price return and stock price volatility.

The sample was compiled subject to the following limitation: a company's R\&D expenses should have been more than $\$ 200$ million in 2015. So the data includes 389 innovative firms from nine industries: communications; consumer, cyclical; technology; consumer, non-cyclical; industrial; financial; energy; basic materials; and utilities. Most of chosen companies operate in the industrial sector, 88 holdings. A huge number of firms are from technological and consumer noncyclical industries, $20 \%$ and $21 \%$, respectively. Another $17 \%$ of corporations from the sample are companies from the consumer cyclical sector. The rest of the firms form about $20 \%$ of the total.

It is important to mention that some companies from the sample appeared not so long ago, i.e., some of the firms are less than 10 years old, which is why the sample is unbalanced.

\section{Variables description}

For further investigation, it is necessary to choose variables that can influence both direct and indirect costs of financial distress. Direct costs are equal to bankruptcy probability costs, and indirect costs are unexpected losses/profits.

Ohlson's model was chosen as the basis for the methodology of the first part of the present paper. The difference between the present research and Ohlson's paper is that the first includes only non-bankrupt firms while the second combines both bankrupt and non-bankrupt companies. That is why the interest coverage ratio was chosen as an indicator of financial distress. It is calculated according to the following formula:

Interest covarage ratio $=$

Earnings before interest, taxes,

$=\frac{\text { depreciation and amortization }}{\text { Interest expenses }}$.

Thus, dependent dummy variable $y$ is equal to 1 if the interest coverage ratio is lower than 1 and 0 otherwise.

Financial independent variables were taken from Ohlson's paper. A more detailed explanation is given below in Table 3 .

The first factor is the Size. It is added in order to take into account the effect of scale. The indicators that describe financial stability are financial Leverage, dummy variables that show whether debt exceeds total assets or not, and Cash flows provided by operations divided by total liabilities. The Dummy for leverage "serves as a discontinuity correction for financial leverage" [Ohlson, 1980]. Ohlson calculated leverage according to the total debt-to-total assets ratio, but this factor yielded insignificant results. So,

RMJ 16 (1): 37-62 (2018) 
Table 3

Independent financial variables

\begin{tabular}{|c|c|c|}
\hline Variable & Label & Measure \\
\hline Size & Size & $\ln ($ Total assets $)$ \\
\hline Leverage & Leverage & Total debt \\
\hline & & $\overline{\text { Market capitalization of shares }}$ \\
\hline Dummy for leverage & $\begin{array}{l}\text { Ldummy, } \\
\text { L }\end{array}$ & $\left\{\begin{array}{l}1 \text { if Total debt exceeds Total assets, } \\
0 \text { if otherwise }\end{array}\right.$ \\
\hline Operating cash flow scaled by total debt & Ocftl & $\frac{\text { Operating cash flow }}{\text { Total debt }}$ \\
\hline Current ratio & Clca & $\frac{\text { Current liabilities }}{\text { Current assets }}$ \\
\hline Return on assets & $R O A$ & $\frac{\text { Net income }}{\text { Total assets }}$ \\
\hline Working capital scaled by total assets & Wcta & $\frac{\text { Working capital }}{\text { Total assets }}$ \\
\hline Net income growth & Nigrowth & $\frac{N I_{t}-N I_{t-1}}{\left|N I_{t}\right|+\left|N I_{t-1}\right|}$ \\
\hline Dummy for net income & $N n$ & $\left\{\begin{array}{l}1 \text { if Net income was negative last two years, } \\
0 \text { if otherwise }\end{array}\right.$ \\
\hline
\end{tabular}

we decided to use the debt-to-market capitalization ratio in this study. Liquidity is presented by the Current ratio. Profitability ratios are represented by the Return on assets and Working capital scaled by total assets. Besides the listed factors, Ohlson examined the following two factors, which are also taken into account in the present investigation, i.e., Net income growth and the Dummy for net income and whether it was negative over the previous two years.

In addition to the chosen financial factors, it was decided to examine variables according to [Zhang, 2015], which included more firm characteristics and market indicators, stock return volatility and the book-to-market value of total assets, measured as:

$\frac{\text { BVof total assets }}{\text { BVof totalassets }-}$

This paper is devoted to an examination of the innovative firms, and we decided to add industry-specific characteristics and R\&D investment ratios. Zhang suggested four R\&D characteristics, i.e., $R \& D$ expenditures to total assets, to sales, and to the number of employees. The last indicator is R\&D capital to total assets [Zhang, 2015, p.98]. It is calculated as:

$$
\begin{gathered}
R D C_{i, t}=R D_{i, t}+0.8 \cdot R D_{i, t-1}+ \\
+0.6 \cdot R D_{i, t-2}+0.4 \cdot R D_{i, t-3}+0.2 \cdot R D_{i, t-4}
\end{gathered}
$$

These four factors are described in Table 4. Thus, the analysis includes 15 independent variables: financial and non-financial firm characteristics as well as market and industry factors.

\section{Methodology}

Most papers devoted to evaluation of financial distress costs use panel data in order to obtain more accurate coefficients and clearer predictions. Today there are many proposed methodologies, but none can yield 
Table 4

$R \& D$ indicators

\begin{tabular}{l|l|l}
\hline \multicolumn{1}{c|}{ Variable } & Label & \multicolumn{1}{c}{ Measure } \\
\hline R\&D expenditures scaled by total assets & $R d a$ & $\frac{R \& D \text { expenditures }}{\text { Total assets }}$ \\
\hline R\&D expenditures scaled by sales & $R d s$ & $\frac{R \& D \text { expenditures }}{\text { Sales }}$ \\
\hline R\&D expenditures scaled by number of employees & $R d e$ & $\frac{R \& D \text { expenditures }}{\text { Number of } \text { employees }}$ \\
\hline R\&D capital scaled by total assets & Rdcta & $\frac{R \& D \text { capital }}{\text { Total assets }}$ \\
\hline
\end{tabular}

perfect results that contain each country, industry or even firm. The most widespread approaches include multiple discriminant analysis, binary regressions, and neural networks. After comparing the pros and cons of each method, we decided to opt for the binary choice model in this investigation, in particular, a logit regression. Ohlson's model modification will serve as the basis for an evaluation of direct financial distress costs, given that it seems necessary to include macroeconomic and market variables in the analysis, as [Zhang, 2015] did. Indirect financial distress costs will be estimated as profit losses/gains according to Altman's analysis.

\section{Methodology of the evaluation of direct financial costs}

One of the assumptions of the present paper is that direct distress financial costs are equal to bankruptcy costs, as there is no common opinion on this term.

A huge amount of previous empirical studies have tried to find out which model predicts bankruptcy better than others, but they did not reach a common conclusion. In 2006, Aziz and Dar came to the conclusion that the most popular methods for calculating direct financial distress costs are statistical methods, i.e. multiple discriminant analysis and binary choice models are the most frequently used. However, multiple discriminant analysis has a significant disadvantage - the existence of a "grey zone" where the probability of bankruptcy cannot be predicted. This is why the binary choice model, the logistic regression, was selected as the basis for this part of the analysis.

Variable $y_{i, t}$ is the dependent variable of firm $i$ in year $t$. It takes the value 1 if the interest coverage ratio is lower than 1 and 0 if otherwise. $x_{i, t}$ are the independent variables. The function of the probability that $y_{i, t}$ takes a value of 1 is described by the formula (4):

$$
P\left[y_{i, t}=1 \mid x_{i, t}, \beta, \alpha_{i}\right]=\Lambda\left(\alpha_{i}+x_{i, t}^{\prime} \beta\right),
$$

where $\Lambda\left(\alpha_{i}+x_{i, t}^{\prime} \beta\right)$ is the logistic cumulative distribution function with $\Lambda(y)=\frac{e^{y}}{1+e^{y}}$ [Cameron, 2005, p. 795]. Here $y_{i, t}$ can be found as a function from the independent variables (5):

$$
y_{i, t}=\beta^{\prime} x_{i, t} .
$$

The joint density function of company $i$ is

$$
\begin{aligned}
f\left(y_{i} \mid X_{i}, \beta, \alpha_{i}\right) & =\prod_{t=1}^{T} F\left(\alpha_{i}+x_{i, t}^{\prime} \cdot \beta\right)^{y_{i, t}} \times \\
& \times\left(1-F\left(\alpha_{i}+x_{i, t}^{\prime} \cdot \beta\right)\right)^{1-y_{i, t}} .
\end{aligned}
$$

Furthermore, the analysis is based on panel data that gives an opportunity for using the extended version of the logit regression, i.e., the panel logit regression, 
which can be estimated through fixed effect and random effect models.

The random effect binary model assumes that the firm-specific effect is a random variable and that it is uncorrelated with the independent variables. This approach supposes that individual effects submit to a normal distribution $\varepsilon_{i, t} \sim N\left(0, \sigma_{e}^{2}\right), \alpha_{i, t} \sim N\left(0, \sigma_{\alpha}^{2}\right)$ and that the joint density function is given in the following formula:

$$
\begin{aligned}
& f\left(y_{i} \mid X_{i}, \beta, \sigma_{\alpha}^{2}\right)= \\
& =\int\left(y_{i} \mid X_{i}, \beta, \alpha_{i}\right) \frac{1}{\sqrt{2 \pi \sigma_{\alpha}^{2}}} e^{\frac{-\alpha_{i}^{2}}{2 \sigma_{\alpha}^{2}}} d \alpha_{i} .
\end{aligned}
$$

The fixed effect model assumes that firmspecific effect is a random factor, but in contrast to random effect model, it can be correlated with independent factors. The joint density for firm $i$ of this model is

$$
f\left(y_{i} \mid X_{i}, \beta, \alpha_{i}\right)=\frac{e^{\alpha_{i} \sum_{t} y_{i, t}} \cdot e^{\left(\sum_{t} y_{i, t} \cdot x_{, t}^{\prime}\right) \cdot \beta}}{\prod_{t}\left[1+e^{\alpha_{i}+x_{i, t}^{\prime} \cdot \beta}\right]} .
$$

Thus, the functions for the dependent variable look as follows

1) $y_{i, t}=\alpha+x_{i, t} \cdot \beta+\left(u_{i}+\vartheta_{i, t}\right)$ for the random effect model;

2) $y_{i, t}=\left(\alpha+u_{i}\right)+x_{i, t} \cdot \beta+\vartheta_{i, t}$ for the fixed effect model.

In our case, the dependent variable is described by 12 independent factors:

$$
\begin{gathered}
y_{i, t}=\alpha_{i}+\beta_{1} \cdot \text { Size }_{i, t}+\beta_{2} \cdot \text { Leverage }_{i, t}+ \\
+\beta_{3} \cdot L_{i, t}+\beta_{4} \cdot \text { Ocftd }_{i, t}+\beta_{5} \cdot \text { Clca }_{i, t}+ \\
+\beta_{6} \cdot \text { ROA }_{i, t}+\beta_{7} \cdot \text { Wcta }_{i, t}+\beta_{8} \cdot \text { Nigrowt }_{i, t}+ \\
+\beta_{9} \cdot N n_{i, t}+\beta_{10} \cdot \text { Bm }_{i, t}+\beta_{11} \cdot \text { Vol }_{i, t}+ \\
+\beta_{12} \cdot R \& D \text { indicator }_{i, t}+\varepsilon_{i, t} \cdot
\end{gathered}
$$

The logic is that the original Ohlson model will be regressed, and after that, market and industry factors will be added one by one. Special attention should be paid to industry variables, i.e., four R\&D expenditures indicators are included, but the four models will be evaluated with each factor separately.
After constructing the models, the one with the most predictive power will be chosen.

It should be mentioned that

1) the probability of financial distress rises with $y$;

2) $y=\log \left(\frac{P}{1-P}\right)$.

As Ohlson remarks, these relations make the model easy to interpret [Ohlson, 1980, p. 118].

The quality of the models will be estimated through the area under the receiver operating characteristic $(R O C)$ curve. If it is more than $70 \%$, then such a model has a high level of predictive power. So, the models will be compared according to this criterion.

In order to evaluate the direct financial distress costs the following assumption was taken: the derived probability should be multiplied by the sales of each firm-year observation. The logic here is that if the bankruptcy happens, then sales will be equal to zero with the probability:

$D D C_{i, t}=$

$$
=\text { Probability of bancruptcy' }^{\prime} \text { Sales }_{i, t} \text {. }
$$

Methodology for the evaluation of indirect financial costs

The next step of the methodology is evaluation of indirect financial costs. Previous empirical research does not give such a wide range of choices as in the case of direct costs. Intuitively the indirect costs of financial distress reflect unexpected profit or losses. The first paper where it was estimated was [Altman, 1984]. Nevertheless, it is a relatively old approach that is still popular among analysts.

For a better understanding, a more detailed explanation is given below step by step. The sales of the firm were regressed on total industry sales for the $\mathbf{1 0}$ prior years:

$$
S_{i, t}=\alpha+\beta \cdot S_{I, t}, \quad t=10 \text { years },
$$

where $S_{i, t}$ - sales of firm $i$ in period $t ; S_{I, t}-$ aggregate sales of industry $I$ in period $t$. 
In this case, the sales of firm $i$ at the moment $t$ are the firm's sales in 2015. Industry sales over previous 10 years are the sales of the global industry in 2005-2014.

After that, Altman included aggregate industry sales and obtained estimated company sales:

$$
\hat{S}_{i, t}=\alpha+\beta \cdot S_{I, t} .
$$

Then the author suggests calculating average profit margin for sales over the 10 years prior to the period under consideration. After that, if we multiply estimated sales of the firm by sales margin, we will obtain estimated profit:

$$
\hat{P}_{i, t}=\hat{S}_{i, t} \cdot \overline{P M} .
$$

In order to find the indirect costs, we have to compare real profit with estimated profit, i.e., the difference between them is equal to indirect distress costs [Altman, 1984, p. 1073]:

$$
I D C=\Delta P_{i, t}=P_{i, t}-\hat{P}_{i, t} .
$$

Thus, for each firm we calculate indirect and direct costs of financial distress for 2015. The total value of distress costs is equal to the sum of these two values:

$$
T D C=D D C+I D C .
$$

\section{Results}

\section{Descriptive statistics}

Before moving to our calculations, it is necessary to describe the collected data and check variables for multicollinearity.

The initial number of observation is equal to 3729 for 389 companies, so the sample is unbalanced. There are firms in the sample that were founded between 2006 and 2015, and they have fewer observations present in the sample. The calculation of net income growth also limits the number of observations as they are computed with indicators from previous years.
Unfortunately, there are many outliers. In order to get unbiased results they were dropped from the sample. Final descriptive statistics of the data is given in Table 5 .

Table 5 contains information about mean value, standard deviation, minimum and maximum values of the variables. The overall number of observations is equal to 3714 and 3326 for net income growth. There is huge interval between minimum and maximum value for the factors. It can be explained by the 10-year period of analysis that includes not only the global financial crisis of 2007 , separate recessions in different countries, but also the specific features of the innovative companies since such firms invest a lot in R\&D projects.

Special attention should be paid to the dependent variable $y$. It has a mean value of 0.051 with a standard deviation equal to 0.22. For a better understanding of what happens to the sample, the Table 6 was constructed in Stata 13.0.

It can be concluded that if a firm was not in distress in the previous year, it will be distressed this year with the probability $2.02 \%$, and with a $97.98 \%$ chance that it will become healthy. At the same time, the probability that a company will be distressed this year if it was distressed last year is $62.2 \%$, with a $37.8 \%$ chance that it will become healthy.

The variables were also checked for multicollinearity, and a VIF was constructed for this purpose. It is lower than 5 , so it can be concluded that there is no multicollinearity between the factors (see Appendix).

The second part of the research performs a calculation of unexpected profit or losses as it was suggested by Altman. The following variables are included: a firm's sales for 2015, the aggregate industry sales for 2005-2014, the average profit margin in 2006-2015 for each company, and net income in 2015. All factors are in absolute terms, except for average profit margin, which is calculated as the sum of net income scaled by sales during the 10 years and divided by 10. Descriptive statistics is presented in Table 7. 
Table 5

Descriptive statistics for direct distress costs model

\begin{tabular}{l|c|c|c|c|c}
\hline Variable & Observations & Mean & Std. Dev. & Min & Max \\
\hline$y$ & 3714 & 0.05 & 0.22 & 0 & 1 \\
\hline Size & 3714 & 9.67 & 1.32 & 7.17 & 12.02 \\
\hline Leverage & 3714 & 0.44 & 1.07 & 0 & 27.98 \\
\hline Ldummy & 3714 & 0.11 & 0.31 & 0 & 1 \\
\hline Wcta & 3714 & 0.18 & 0.16 & -0.07 & 0.54 \\
\hline Clca & 3714 & 0.65 & 0.28 & 0.2 & 1.23 \\
\hline ROA & 3714 & 0.06 & 0.06 & -0.06 & 0.17 \\
\hline Ocftl & 3714 & 1.86 & 4.18 & -0.01 & 18.25 \\
\hline Nn & 3714 & 0.05 & 0.21 & 0 & 1 \\
\hline Nigrowth & 3326 & 0.02 & 0.44 & -1 & 1 \\
\hline Vol & 3714 & 0.36 & 0.13 & 0 & 0.65 \\
\hline Bm & 3714 & 0.66 & 0.27 & 0.21 & 1.11 \\
\hline Rda & 3714 & 0.06 & 0.05 & 0 & 0.19 \\
\hline Rds & 3714 & 0.09 & 0.08 & 0 & 0.31 \\
\hline Rde & 3714 & 0.04 & 0.04 & 0 & 0.16 \\
\hline Rdcta & 3714 & 0.12 & 0.13 & 0 & 0.45 \\
\hline & & & & &
\end{tabular}

Table 6

Dependent variable description

\begin{tabular}{c|c|c|c}
\hline$y$ & \multicolumn{1}{|c|}{$\mathbf{0}$} & $\mathbf{1}$ & Total \\
\hline $\mathbf{0}$ & 97.98 & 2.02 & 100 \\
\hline $\mathbf{1}$ & 37.8 & 62.2 & 100 \\
\hline Total & 95.01 & 4.99 & 100 \\
\hline
\end{tabular}

Table 7

Descriptive statistics for indirect distress costs model

\begin{tabular}{l|c|c|c|c|c}
\hline \multicolumn{1}{c|}{ Variable } & $\boldsymbol{N}$ & Mean & Std. Dev. & Min & Max \\
\hline Sales & 389 & 30493.49 & 45317.72 & 41.1 & 283934.3 \\
\hline Industry & 389 & 49192.7 & 19413.8 & 21609.2 & 76061.6 \\
\hline Averagepm & 389 & 0.09 & 0.12 & -0.62 & 0.69 \\
\hline Ni & 389 & 2032.97 & 4407.57 & -13494.52 & 53394 \\
\hline
\end{tabular}

Companies' sales and net income have very high standard deviation, but the estimation of indirect distress costs is conducted for each firm separately, so there is no need to drop outliers. As stated above, the firms from the sample operate in nine industries. Sectors' aggregate sales for the 10 years prior to 2015 range from $\$ 21.6$ trillion to $\$ 76.1$ trillion. It is notable that the net income was negative at 42 companies in
2015, even in such giants as Volkswagen, General Electric, Tesla, Yahoo! and so on. This explains why the minimum average profit margin is negative.

\section{Evaluation of direct distress costs}

Estimation of direct financial distress costs is based on panel data analysis. Overall panel data has advantages over the other types of data as it gives an opportunity to take 
Table 8

Initial nine variables: pooled, fixed effect and random effect regressions results

\begin{tabular}{l|c|c|c}
\hline \multirow{2}{*}{ Variable } & \multicolumn{3}{|c}{ Model } \\
\cline { 2 - 4 } & Pooled & Fixed effect & Random effect \\
\hline Size & $-0.4^{* * *}$ & 0.19 & $-0.49^{* *}$ \\
& $(-3.46)$ & $(0.42)$ & $(-2.17)$ \\
\hline Leverage & 0.77 & 0.06 & 0.1 \\
& $(1.33)$ & $(0.18)$ & $(0.94)$ \\
\hline Odummy & -0.32 & $2.49^{* *}$ & 0.42 \\
& $(-0.92)$ & $(2.17)$ & $(0.68)$ \\
\hline Clca & $-0.23^{* *}$ & $-1.35^{*}$ & $-0.34^{* *}$ \\
& $(-2.51)$ & $(-1.68)$ & $(-2.53)$ \\
\hline ROA & $4.14^{* *}$ & 2.41 & $5.83^{*}$ \\
& $(2.49)$ & $(0.44)$ & $(1.83)$ \\
\hline Wcta & $-37.03^{* * *}$ & $-55.23^{* * *}$ & $-58.35^{* * *}$ \\
& $(-10.23)$ & $(-5.44)$ & $(-7.57)$ \\
\hline Nigrowth & 0.11 & -3.78 & -0.61 \\
& $(0.11)$ & $(-1.13)$ & $(-0.33)$ \\
\hline Nn & -0.14 & -0.1 & -0.6 \\
& $(-0.58)$ & $(-0.26)$ & $(-0.18)$ \\
\hline Constant & $0.74^{* *}$ & -0.19 & 0.55 \\
& $(2.22)$ & $(-0.29)$ & $(1.04)$ \\
\hline Observations & 0.21 & & -0.73 \\
\hline Pseudo $R^{2}$ & $(0.14)$ & & $(-0.25)$ \\
\hline LR chi ${ }^{2}(9)$ & 7326 & 528 & 3326 \\
\hline Wald chi ${ }^{2}(9)$ & 0.549 & & 88.06 \\
\hline Prob $>$ chi $^{2}$ & 0.0000 & 0.0000 & 0.0000 \\
\hline
\end{tabular}

N o te: Z-statistics based on standard errors are in parentheses;

$*, * *$ and $* * *$ indicate statistical significance at the $10 \%, 5 \%$ and $1 \%$ levels, respectively.

into account individual differences of entities during various periods of time.

There are two main models that analyze the panel data:

1) random effect regression;

2) fixed effect regression.

The crucial difference between these two models is in unobserved firms' effect (it includes factors that correlate with the regressors). The fixed effect model supposes that there can be a connection, but the random effect model assumes that unobserved effects do not have such relationships with other variables and that they only influence residuals.
The basic Ohlson model is estimated with random and fixed effect models, and then the one best suited for estimating the probability of financial distress is chosen. After that, industry and market variables are included one by one in this chosen model. However, before the panel data analysis, it is necessary to run a pooled regression. The pooled regression perceives the sample not as panel data but as a cross-section, i.e., it does not take the individual characteristic of an entity that changes over a period of time into account.

The outcomes of the three regressions are given in Table 8. 
All three models are significant as the chi-square is lower than 0.05; the hypothesis that their coefficients are equal to 0 was rejected. In the pooled regression, the coefficients behind Size, operating cash flow scaled by total debt (Ocftl), current ratio $(C l c a)$, return on assets (ROA), dummy for net income $(\mathrm{Nn})$ were significant at $5 \%$, Leverage at $20 \%$. The rest of coefficients were not significant even at a $30 \%$ level. This model yields more significant coefficients than the other two.

The random effect model shows almost the same meaningful coefficients, except the dummy variable for net income, which nevertheless has the same positive influence. Ldummy and Wcta change their signs, but remain insignificant.

While running the fixed effect model, the number of observations and groups was dropped by the system, obviously because of unbalanced sample. The model shows two significant factors, i.e. the Ldummy and ROA at a $5 \%$ significance level. Besides, Ocftl is significant at a $10 \%$ level.

Overall, it was unexpected that the other factors would yield insignificant results, but in order to overcome this, we decided to adjust the models with dummies for years. The results are presented in Table 9 .

Although all three models are significant at a $1 \%$ level, the situation did not change noticeably. The dummies for years yielded significant results in 2012, 2014, and 2015. Year of 2012 can be explained by the results of the global financial crisis. Most interesting are 2014 and 2015 as they show that the financial results for the previous two years had a positive influence on the probability of financial distress. Models demonstrate that the coefficients behind Size, Ocftl, ROA, 2014, and 2015 are significant. That means that the more assets a firm has, the lower is the probability of financial distress. Return on assets and Operating cash flows scaled by total debt have the same sign and influence the dependent variable adversely.

The pooled regression pseudo $R$-squared increased slightly, from $54.9 \%$ to $56.23 \%$, and Leverage became significant at a $10 \%$ level. Fixed effect models show the causes of variation within a company, and as mentioned above, some companies were founded during the observation period, which reduces the size of the sample. This is perhaps why the coefficients do not demonstrate significant values. The random effect model also did not change, except in that Net income growth sign varies, but its coefficient yields an insignificant result.

Thus, it is necessary to determine which model is better than the other two. To start with, the fixed effect model should be compared with the random effect model and with the pooled regression. It seems appropriate to use the Hausman test for this purpose. The null hypothesis suggests the random effect model, and if the null hypothesis is rejected, then the fixed effect model will be preferred as it is better suited. An estimation of the fixed effect model vs. the random effect model is presented in Table 10. The Hausman test did not yield any statistical

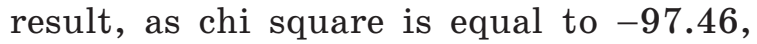
which is less than 0 .

The next pair that should be compared is the fixed effect model vs. the pooled regression. It is also evaluated with the Hausman test. The outcome is presented in Table 11. As a consequence of the Hausman test, the pooled regression is more appropriate than fixed effect model. The $p$-value is much higher than 0.05 , so the null hypothesis, that the pooled model is preferred, was not rejected. Notably, both pairs of tests, the fixed/random and fixed/pooled, showed that the fixed effect model is worse. This is probably due to the unbalanced sample.

The last pair that should be examined is the random effect model and pooled regression. When estimating the random effect model, we run a test, whether the fraction of dependent variable's variance due to error between entities is significant or not. This fraction is called rho. So, if it is not equal to 0 , then the random effect model is preferred over the pooled regression. In this study, it can be concluded that the random 
Table 9

Initial nine variables: corrected pooled, fixed effect and random effect regression results

\begin{tabular}{|c|c|c|c|}
\hline \multirow{2}{*}{ Variable } & \multicolumn{3}{|c|}{ Model } \\
\hline & Pooled & Fixed effect & Random effect \\
\hline Size & $\begin{array}{c}-0.47 * * * \\
(-3.94)\end{array}$ & $\begin{array}{l}-0.43 \\
(-0.75)\end{array}$ & $\begin{array}{c}-0.77 * * * \\
(-2.94)\end{array}$ \\
\hline Leverage & $\begin{array}{c}0.1^{*} \\
(1.89)\end{array}$ & $\begin{array}{c}0.06 \\
(0.28)\end{array}$ & $\begin{array}{c}0.17 \\
(1.53)\end{array}$ \\
\hline Ldummy & $\begin{array}{c}-0.19 \\
(-0.52)\end{array}$ & $\begin{array}{l}3.28 \% * \\
(2.44)\end{array}$ & $\begin{array}{c}0.76 \\
(1.10)\end{array}$ \\
\hline$\overline{O c f t l}$ & $\begin{array}{l}-0.22 * * \\
(-2.54)\end{array}$ & $\begin{array}{l}-1.43^{*} \\
(-1.70)\end{array}$ & $\begin{array}{c}-0.34 * * * \\
(-2.57)\end{array}$ \\
\hline Clca & $\begin{array}{l}4.25 * \% \\
(2.54)\end{array}$ & $\begin{array}{c}2.7 \\
(0.44)\end{array}$ & $\begin{array}{l}6.62 \% \\
(1.93)\end{array}$ \\
\hline$\overline{R O A}$ & $\begin{array}{c}-39.41 * \% * \\
(-10.23)\end{array}$ & $\begin{array}{c}-61.53 * * * \\
(-5.18)\end{array}$ & $\begin{array}{c}-64.15 * * * \\
(-7.2)\end{array}$ \\
\hline$\overline{W c t a}$ & $\begin{array}{c}0.22 \\
(0.22)\end{array}$ & $\begin{array}{c}-3.49 \\
(-0.93)\end{array}$ & $\begin{array}{c}-0.13 \\
(-0.06)\end{array}$ \\
\hline Nigrowth & $\begin{array}{c}-0.14 \\
(-0.57)\end{array}$ & $\begin{array}{c}-0.11 \\
(-0.23)\end{array}$ & $\begin{array}{c}0.12 \\
(-0.33)\end{array}$ \\
\hline$\overline{N n}$ & $\begin{array}{c}0.55 \\
(1.52)\end{array}$ & $\begin{array}{c}-0.68 \\
(-0.88)\end{array}$ & $\begin{array}{c}0.21 \\
(0.34) \\
\end{array}$ \\
\hline 2008 & $\begin{array}{c}-0.21 \\
(-0.35)\end{array}$ & $\begin{array}{c}0.01 \\
(0.01)\end{array}$ & $\begin{array}{c}-0.52 \\
(-0.59)\end{array}$ \\
\hline 2009 & $\begin{array}{c}0.74 \\
(1.29)\end{array}$ & $\begin{array}{l}1.99 \% \\
(1.84)\end{array}$ & $\begin{array}{c}1.33 \\
(1.56)\end{array}$ \\
\hline 2010 & $\begin{array}{c}0.83 \\
(1.26)\end{array}$ & $\begin{array}{l}1.95 * \\
(1.72)\end{array}$ & $\begin{array}{c}1.51 \\
(1.57)\end{array}$ \\
\hline 2011 & $\begin{array}{c}0.5 \\
(0.81)\end{array}$ & $\begin{array}{c}1.53 \\
(1.28)\end{array}$ & $\begin{array}{c}1.13 \\
(1.20)\end{array}$ \\
\hline 2012 & $\begin{array}{l}1.09 * \\
(1.91)\end{array}$ & $\begin{array}{l}2.05^{*} \\
(1.89)\end{array}$ & $\begin{array}{l}1.61 * \\
(1.85)\end{array}$ \\
\hline 2013 & $\begin{array}{c}0.49 \\
(0.78)\end{array}$ & $\begin{array}{l}1.05 \\
(0.9)\end{array}$ & $\begin{array}{c}0.72 \\
(0.77)\end{array}$ \\
\hline 2014 & $\begin{array}{l}1.3 \% * \\
(2.14)\end{array}$ & $\begin{array}{l}2.32 \% \\
(1.95)\end{array}$ & $\begin{array}{l}2.09 * \% \\
(2.24)\end{array}$ \\
\hline 2015 & $\begin{array}{l}1.17 * * \\
(1.99)\end{array}$ & $\begin{array}{c}1.78 \\
(1.56)\end{array}$ & $\begin{array}{l}1.82 \% * \\
(2.02)\end{array}$ \\
\hline Constant & $\begin{array}{c}0.3 \\
(0.02) \\
\end{array}$ & & $\begin{array}{c}0.08 \\
(0.02) \\
\end{array}$ \\
\hline Observations & 3326 & 528 & 3326 \\
\hline Pseudo $R^{2}$ & 0.5623 & & \\
\hline LR $\operatorname{chi}^{2}(9)$ & 741.49 & 225.40 & \\
\hline Wald $\operatorname{chi}^{2}(9)$ & & & 73.71 \\
\hline$\overline{\text { Prob }>\mathrm{chi}^{2}}$ & 0.0000 & 0.0000 & 0.0000 \\
\hline
\end{tabular}

$\mathrm{N}$ o t e: Z-statistics based on standard errors are in parentheses;

$*, * *$ and $* * *$ indicate statistical significance at the $10 \%, 5 \%$ and $1 \%$ levels, respectively. 
Table 10

Fixed effect vs. random effect models, Hausman test

\begin{tabular}{l|c}
\hline Variable & Difference between random and fixed effect models \\
\hline Size & 0.34 \\
\hline Leverage & -0.1 \\
\hline Ldummy & 2.5 \\
\hline Ocftl & -1.09 \\
\hline Clca & -3.92 \\
\hline ROA & 2.62 \\
\hline Wcta & -3.37 \\
\hline Nigrowth & 0.1 \\
\hline Nn & -0.88 \\
\hline 2008 & 0.53 \\
\hline 2009 & 0.66 \\
\hline 2010 & 0.45 \\
\hline 2011 & 0.4 \\
\hline 2012 & 0.45 \\
\hline 2013 & 0.33 \\
\hline 2014 & 0.23 \\
\hline 2015 & -0.4 \\
\hline Chi ${ }^{2}(17)=-97.46<0$ & \\
\hline
\end{tabular}

Table 11

Fixed effect model vs. pooled regression, Hausman test

\begin{tabular}{l|c}
\hline Variable & Difference between random and fixed effect models \\
\hline Size & 0.04 \\
\hline Leverage & -0.04 \\
\hline Ldummy & 3.46 \\
\hline Ocftl & -1.2 \\
\hline Clca & -1.58 \\
\hline ROA & -22.11 \\
\hline Wcta & -3.72 \\
\hline Nigrowth & 0.03 \\
\hline Nn & -1.23 \\
\hline 2008 & 0.22 \\
\hline 2009 & 1.25 \\
\hline 2010 & 1.12 \\
\hline 2011 & 1.03 \\
\hline 2012 & 0.96 \\
\hline 2013 & 0.56 \\
\hline 2014 & 1.02 \\
\hline 2015 & 0.62 \\
\hline Chi $^{2}(17)=16.64$ & \\
Prob $>$ chi $^{2}=0.4788$ & \\
\hline
\end{tabular}


Table 12

Random effect model with a robustness check

\begin{tabular}{|c|c|}
\hline Variable & Coefficients \\
\hline Size & $\begin{array}{c}-0.77 * * * \\
(-3.29)\end{array}$ \\
\hline Leverage & $\begin{array}{c}0.17 * \\
(1.72) \\
\end{array}$ \\
\hline$\overline{L d u m m y}$ & $\begin{array}{c}0.76 \\
(1.06)\end{array}$ \\
\hline$\overline{O c f t l}$ & $\begin{array}{l}-0.34 \% * \\
(-2.35)\end{array}$ \\
\hline$\overline{C l c a}$ & $\begin{array}{l}6.62 * \% \\
(2.16)\end{array}$ \\
\hline$\overline{R O A}$ & $\begin{array}{c}-64.15 * * * \\
(-6.00)\end{array}$ \\
\hline Wcta & $\begin{array}{c}-0.13 \\
(-0.06)\end{array}$ \\
\hline Nigrowth & $\begin{array}{c}-0.12 \\
(-0.30)\end{array}$ \\
\hline$N n$ & $\begin{array}{c}0.21 \\
(0.31)\end{array}$ \\
\hline 2008 & $\begin{array}{c}-0.52 \\
(-0.81) \\
\end{array}$ \\
\hline 2009 & $\begin{array}{l}1.33 \% \\
(1.93)\end{array}$ \\
\hline 2010 & $\begin{array}{c}1.51 \\
(1.62)\end{array}$ \\
\hline 2011 & $\begin{array}{c}1.13 \\
(1.42)\end{array}$ \\
\hline 2012 & $\begin{array}{l}1.61 \% * \\
(2.21) \\
\end{array}$ \\
\hline 2013 & $\begin{array}{c}0.72 \\
(0.85) \\
\end{array}$ \\
\hline 2014 & $\begin{array}{c}2.09 * * * \\
(3.08)\end{array}$ \\
\hline 2015 & $\begin{array}{l}1.82 * * \\
(2.49) \\
\end{array}$ \\
\hline Constant & $\begin{array}{c}0.08 \\
(0.03) \\
\end{array}$ \\
\hline Observations & 3326 \\
\hline Wald $\operatorname{chi}^{2}(17)$ & 73.71 \\
\hline Prob > chi ${ }^{2}$ & 0.0000 \\
\hline
\end{tabular}

N ote: Z-statistics based on standard errors are in parentheses;

$*, * *$ and $* * *$ indicate statistical significance at the $10 \%, 5 \%$ and $1 \%$ levels, respectively. effect model is better than pooled regression, as the hypothesis of rho equal to 0 was rejected at a $1 \%$ significance level.

Therefore, if the pooled regression is better than the fixed model, and random is better than pooled, it can be concluded that the random effect model is the best. However, it seems unforeseeable that some variables have insignificant coefficients with a $p$-value higher than 0.1 , for example, leverage should logically have an influence. Perhaps it occurs due to the heteroscedasticity of the sample. That is why the random effect model is adjusted and standard errors are clustered at the firm level to deal with potential heteroscedasticity. The results of the regression checked for robustness are presented in Table 12.

The outcome of the random effect logit regression checked for robustness showed that Size, Ocftl, Clca and ROA are significant. Leverage shows positive impact on the probability of distress at $10 \%$ significance level.

The economic interpretation for the size of a company is the same as for the initial random effect model, i.e., the larger the company, the lower is the probability of bankruptcy. Leverage and the Ocftl ratios are based on the total debt level and show that the higher debt is, the more likely is insolvency. However, in Leverage debt is the numerator, so the impact of the debt to market capitalization ratio is positive, and Operating cash flows to total debt influences the dependent variable in a negative manner. The current liability to current assets ratio ( $\mathrm{Clca}$ ) has positive relationship with the probability of bankruptcy. Return on assets influences the likelihood of insolvency negatively as the higher net income is, the higher is the interest coverage ratio. Thus, the dummy for interest coverage yields 0 value.

It should be mentioned that the dummy variables for the years also yield significant results in 2009, 2012, 2014, and 2015.

The next step of the research supposes adding market variables to the chosen model. 
These include stock return volatility and the total assets book to market value ratio. The results are presented in Table 13 .

The new added variables show significant results, i.e., $\mathrm{Bm}$ at a $5 \%$ significance level and $\mathrm{Vol}$ at $10 \%$. It is also noticeable that other significant factors' $p$-value changed only slightly, i.e., it rose for Size and Clca. On the contrary, it fell for Leverage and Ocftl. Overall, at a $10 \%$ level the market variables are significant, and there are seven significant coefficients: Size, Leverage, Ocftl, Clca, ROA, Vol, and Bm.

The next part of the investigation is focused on the industry indicators, i.e., the four R\&D ratios. They are separately added to the model. The results are compiled in Table 14.

Three of the R\&D indicators demonstrated a positive influence on the probability of financial distress, i.e., $R \& D$ to assets, $R \& D$ to sales, and $R \& D$ to the number of employees. However, only the last two yield significant results. Model 4 highlighted the meaningful negative coefficient behind the innovative sector index. It can be explained by the fact that this factor includes R\&D expenses for the previous four years, and the logic is the following: if a firm invests in innovative project(s) for such a long period of time, then it (they) must be profitable. Intuitively, this is why the sign is negative.

Size has a significant influence only in Model 4 and it has negative impact. Leverage, Ocftl, ROA, and $\mathrm{Vol}$ also demonstrated significant results in each model, unlike Ldummy, Wcta, Nigrowth, and Nn. Clca variable is insignificant in Models 1 and 3, but in Models 2 and 4 it demonstrates a positive influence upon the probability of insolvency. There is a negative relationship between $\mathrm{Bm}$ and the dependent variable in Models 1 and 4 .

Thus, there are four models with $R \& D$ indicators. However, even if Model 1 will not be taken into account given that its coefficient is insignificant, the model that operates best and predicts the probability of bankruptcy most accurately should be
Table 13

Model with market variables

\begin{tabular}{|c|c|}
\hline Variable & Coefficients \\
\hline Size & $\begin{array}{l}-0.47 * \\
(-1.74)\end{array}$ \\
\hline Leverage & $\begin{array}{l}0.17 * * \\
(2.02)\end{array}$ \\
\hline Ldummy & $\begin{array}{c}0.9 \\
(1.26)\end{array}$ \\
\hline$\overline{O c f t l}$ & $\begin{array}{l}-0.34 * * \\
(-2.44)\end{array}$ \\
\hline$\overline{C l c a}$ & $\begin{array}{c}4.9 * \\
(1.60)\end{array}$ \\
\hline$\overline{R O A}$ & $\begin{array}{l}-61 * * * \\
(-5.77)\end{array}$ \\
\hline Wcta & $\begin{array}{c}-0.7 \\
(-0.35)\end{array}$ \\
\hline Nigrowth & $\begin{array}{c}-0.14 \\
(-0.33)\end{array}$ \\
\hline$\overline{N n}$ & $\begin{array}{l}-0.04 \\
(0.06)\end{array}$ \\
\hline$\overline{\mathrm{Vol}}$ & $\begin{array}{c}4.1 * \\
(1.82)\end{array}$ \\
\hline $\mathrm{Bm}$ & $\begin{array}{l}-2.54 * * \\
(-2.06)\end{array}$ \\
\hline 2008 & $\begin{array}{c}-0.59 \\
(-0.74)\end{array}$ \\
\hline 2009 & $\begin{array}{c}0.74 \\
(0.92)\end{array}$ \\
\hline 2010 & $\begin{array}{l}1.74 \% \\
(1.92)\end{array}$ \\
\hline 2011 & $\begin{array}{l}1.39 * \\
(1.61)\end{array}$ \\
\hline 2012 & $\begin{array}{l}1.63 * * \\
(2.21)\end{array}$ \\
\hline 2013 & $\begin{array}{c}0.74 \\
(0.84)\end{array}$ \\
\hline 2014 & $\begin{array}{c}2.35 \% * * \\
(3.26)\end{array}$ \\
\hline 2015 & $\begin{array}{l}1.86 \% * \\
(2.47)\end{array}$ \\
\hline Constant & $\begin{array}{c}-1.8 \\
(-0.68)\end{array}$ \\
\hline Observations & 3326 \\
\hline Wald chi $^{2}(17)$ & 82.53 \\
\hline Prob > chi ${ }^{2}$ & 0.0000 \\
\hline
\end{tabular}

N ot e: Z-statistics based on standard errors are in parentheses;

$*$, $* *$ and $* * *$ indicate statistical significance at the $10 \%, 5 \%$ and $1 \%$ levels, respectively. 
Table 14

Four models with $R \& D$ indicators

\begin{tabular}{|c|c|c|c|c|}
\hline \multirow{2}{*}{ Variable } & \multicolumn{4}{|c|}{ Coefficients } \\
\hline & Model 1 & Model 2 & Model 3 & Model 4 \\
\hline Size & $\begin{array}{l}-0.378 \\
(-1.36)\end{array}$ & $\begin{array}{l}-0.208 \\
(-0.75)\end{array}$ & $\begin{array}{l}-0.407 \\
(-1.54)\end{array}$ & $\begin{array}{c}-0.744 * * \\
(-2.30)\end{array}$ \\
\hline Leverage & $\begin{array}{c}0.173 * * \\
(2.01)\end{array}$ & $\begin{array}{l}0.173^{*} \\
(1.91)\end{array}$ & $\begin{array}{l}0.156^{*} \\
(1.70)\end{array}$ & $\begin{array}{c}0.177 * * \\
(2.00)\end{array}$ \\
\hline$\overline{L d u m m y}$ & $\begin{array}{l}0.923 \\
(1.26)\end{array}$ & $\begin{array}{c}1.12 \\
(1.43)\end{array}$ & $\begin{array}{l}0.975 \\
(1.32)\end{array}$ & $\begin{array}{c}0.781 \\
(1.13)\end{array}$ \\
\hline$\overline{\text { Ocftl }}$ & $\begin{array}{c}-0.351 * * \\
(-2.43)\end{array}$ & $\begin{array}{c}-0.38 * * \\
(-2.59)\end{array}$ & $\begin{array}{c}-0.359 * * \\
(-2.53)\end{array}$ & $\begin{array}{c}-0.341 * * \\
(-2.46)\end{array}$ \\
\hline$\overline{C l c a}$ & $\begin{array}{c}4.68 \\
(1.53)\end{array}$ & $\begin{array}{l}5.744^{*} \\
(1.79)\end{array}$ & $\begin{array}{c}4.592 \\
(1.53)\end{array}$ & $\begin{array}{c}5.233 * \\
(1.73)\end{array}$ \\
\hline$\overline{R O A}$ & $\begin{array}{c}-60.41 * * * \\
(-5.56)\end{array}$ & $\begin{array}{l}-59 * * * \\
(-5.39)\end{array}$ & $\begin{array}{c}-60.048 * * * \\
(-5.58)\end{array}$ & $\begin{array}{c}-64.003 * * * \\
(-5.51)\end{array}$ \\
\hline$\overline{W c t a}$ & $\begin{array}{l}-0.824 \\
(-0.41)\end{array}$ & $\begin{array}{l}0.199 \\
(0.10)\end{array}$ & $\begin{array}{l}-0.513 \\
(-0.25)\end{array}$ & $\begin{array}{l}-0.554 \\
(-0.29)\end{array}$ \\
\hline$\overline{\text { Nigrowth }}$ & $\begin{array}{l}-0.144 \\
(-0.35)\end{array}$ & $\begin{array}{l}-0.191 \\
(-0.45)\end{array}$ & $\begin{array}{l}-0.143 \\
(-0.35)\end{array}$ & $\begin{array}{l}-0.14 \\
(-34)\end{array}$ \\
\hline$\overline{N n}$ & $\begin{array}{l}-0.066 \\
(-0.10)\end{array}$ & $\begin{array}{l}-0.133 \\
(-0.20)\end{array}$ & $\begin{array}{l}-0.109 \\
(-0.16)\end{array}$ & $\begin{array}{l}0.286 \\
(0.43)\end{array}$ \\
\hline$\overline{\mathrm{Vol}}$ & $\begin{array}{l}4.183^{*} \\
(1.84) \\
\end{array}$ & $\begin{array}{c}4.777 * * \\
(2.03)\end{array}$ & $\begin{array}{l}4.314^{*} \\
(1.87)\end{array}$ & $\begin{array}{l}4.11 \% \\
(1.87)\end{array}$ \\
\hline $\mathrm{Bm}$ & $\begin{array}{l}-2.34 \% \\
(-1.84) \\
\end{array}$ & $\begin{array}{l}-1.523 \\
(-1.14)\end{array}$ & $\begin{array}{l}-2.009 \\
(-1.55) \\
\end{array}$ & $\begin{array}{c}-2.678 * * \\
(-2.15)\end{array}$ \\
\hline$\overline{R d a}$ & $\begin{array}{c}5.14 \\
(0.76)\end{array}$ & & & \\
\hline$R d s$ & & $\begin{array}{c}12.553 * \% \\
(2.54)\end{array}$ & & \\
\hline$\overline{R d e}$ & & & $\begin{array}{c}11.756^{*} \\
(1.78)\end{array}$ & \\
\hline Rdcta & & & & $\begin{array}{c}-5.543 * * \\
(-2.06)\end{array}$ \\
\hline Observations & 3326 & 3326 & 3326 & 3326 \\
\hline Wald chi $^{2}$ & 76.33 & 56.57 & 72.43 & 81.90 \\
\hline$\overline{\text { Prob }>\text { chi }^{2}}$ & 0.0000 & 0.0000 & 0.0000 & 0.0000 \\
\hline
\end{tabular}

Note: Z-statistics based on standard errors are in parentheses;

$*, * *$ and $* * *$ indicate statistical significance at the $10 \%, 5 \%$ and $1 \%$ levels, respectively.

Table 15

\section{ROC curve estimates}

\begin{tabular}{c|l|l|l|c}
\hline Model & Model 1 & Model 2 & Model 3 & Model 4 \\
\hline Area under LROC & 0.9399 & 0.9365 & 0.9370 & 0.9452 \\
\hline
\end{tabular}

chosen. In this case, a receiver operating characteristics (ROC) curve is constructed and the area under this curve is calculated. The results are presented in Table 15. 
Thus, it can be concluded that Model 4 is the best one. It predicts insolvency with a probability of $94.52 \%$. The final equation (Model 4) has the following form (16)

$$
\begin{gathered}
y_{i, t}=0.28-0.74 \cdot \text { Size }_{i, t}+0.18 \cdot \text { Leverage }_{i, t}+ \\
+0.78 \cdot L_{i, t}-0.34 \cdot \text { Ocftd }_{i, t}+5.23 \cdot \text { Clca }_{i, t}{ }^{-} \\
-64 \cdot \text { ROA }_{i, t}-0.55 \cdot \text { Wcta }_{i, t}- \\
-0.14 \cdot \text { Nigrowth }_{i, t}+0.29 \cdot \mathrm{Nn}_{i, t}- \\
-2.68 \cdot \text { Bm }_{i, t}+4.11 \cdot \text { Vol }_{i, t}- \\
-5.54 \cdot \text { Rdcta }_{i, t}+\varepsilon_{i, t}
\end{gathered}
$$

The outcome is presented in Table 16.

After that, the probability of distress is calculated in Stata $\mathbf{1 3 . 0}$ as a post estimation. Next, in order to obtain the absolute value of direct distress costs, this value is multiplied by sales. Relative values are also evaluated as the direct distress costs scaled by total assets and by value of a company. The overall results are presented in Table 17.

\section{Evaluation of indirect costs}

An ordinary least squares regression of a company's sales on the aggregate sales of the industry for the ten prior years was conducted. The outcome of the model yields a significant result for the independent variable at a $1 \%$ level. Thus, the following equation is provided:

Sales $_{2015}=4867.269+0.0005264 \times$

$\times$ Aggregate industry sales ${ }_{2005-2014}+\varepsilon$.

In order to find estimated sales for each

\begin{tabular}{|c|c|}
\hline Variable & Coefficients \\
\hline Size & $\begin{array}{l}-0.74 * * \\
(-2.30)\end{array}$ \\
\hline Leverage & $\begin{array}{l}0.18 * * \\
(2.00)\end{array}$ \\
\hline Ldummy & $\begin{array}{c}0.78 \\
(1.13)\end{array}$ \\
\hline Ocftl & $\begin{array}{l}-0.34 * * \\
(-2.46)\end{array}$ \\
\hline Clca & $\begin{array}{l}5.23 * \\
(1.73)\end{array}$ \\
\hline$R O A$ & $\begin{array}{l}-64 * * * \\
(-5.51)\end{array}$ \\
\hline Wcta & $\begin{array}{c}-0.55 \\
(-0.29)\end{array}$ \\
\hline Nigrowth & $\begin{array}{c}-0.14 \\
(-0.34)\end{array}$ \\
\hline$N n$ & $\begin{array}{c}0.29 \\
(0.43)\end{array}$ \\
\hline Vol & $\begin{array}{l}4.11 * \\
(1.87)\end{array}$ \\
\hline$B m$ & $\begin{array}{l}-2.68 * * \\
(-2.15)\end{array}$ \\
\hline Rdcta & $\begin{array}{c}-5.54 * \% \\
(-2.06)\end{array}$ \\
\hline Constant & 0.28 \\
\hline Observations & 3326 \\
\hline Wald chi $^{2}$ & 81.90 \\
\hline Prob $>$ chi $^{2}$ & 0.0000 \\
\hline
\end{tabular}
company, the amount of aggregate industry sales for 2005-2014 is substituted in every of 389 cases.
Table 16

Insolvency prediction with Model 4

Note: Z-statistics based on standard errors are in parentheses;

$*, * *$ and $* * *$ indicate statistical significance at the $10 \%, 5 \%$ and $1 \%$ levels, respectively.

Furthermore, the mean profit margin for the ten years from 2006 to 2015 is calculated, and this figure is multiplied by estimated sales of the firms. Such manipulations give

Table 17

Direct distress costs

\begin{tabular}{l|c}
\hline \multicolumn{1}{c|}{ Variable } & Mean value \\
\hline Direct distress costs & $\$ 313.88 \mathrm{mln}$ \\
\hline Direct distress costs/Total assets & $2.6 \%$ \\
\hline Direct distress costs/Value of company & $4.18 \%$ \\
\hline
\end{tabular}


Table 18

Indirect distress costs

\begin{tabular}{l|c}
\hline \multicolumn{1}{c|}{ Variable } & Mean value \\
\hline Indirect distress costs & $\$ 339.84 \mathrm{mln}$ \\
\hline Indirect distress costs/Total assets & $5.35 \%$ \\
\hline Indirect distress costs/Value of company & $7.6 \%$ \\
\hline
\end{tabular}

Table 19

Total distress costs

\begin{tabular}{l|c}
\hline \multicolumn{1}{c|}{ Variable } & Mean value \\
\hline Total distress costs & $\$ 658.72 \mathrm{mln}$ \\
\hline Total distress costs/Total assets & $7.95 \%$ \\
\hline Total distress costs/Value of company & $11.78 \%$ \\
\hline
\end{tabular}

one the opportunity to appraise evaluated profit.

The last step of evaluation of indirect distress costs is take the difference between evaluated net income and real net income. Thus, the indirect financial costs' mean value is equal to $\$ 339.84$ million in 2015 . Average relative values are also calculated, the indirect distress costs scaled by total assets and the value of company amount $5.35 \%$ and $7.6 \%$, respectively (Table 18 ).

It is interesting that $34 \%$ of the firms have positive distress costs, i. e., unexpected profits. The sample includes gigantic holdings, which are developing much more rapidly than their parent industries, so their financial indicators tend predominate those of other holdings.

Thus, both the direct and indirect costs of financial distress are evaluated, and to complete the investigation, the total distress costs are estimated as the sum of direct and indirect distress costs. The results are given in Table 19.

The absolute mean value of total distress costs is approximately $\$ 660$ million. The relative figures show that these costs are equal to $7.95 \%$ of total assets, or $11.78 \%$ of firms' value. The ratios are quite high and should be taken into account when making financial decisions such as the choice of target capital structure.

\section{Conclusion}

We set the goal of evaluating financial distress costs of innovative companies at the beginning of this paper. This was achieved by completing the aforementioned tasks.

To sum up, in Table 20 we compiled information about forecasts and outcomes.

The conducted research gives one an opportunity to conclude that the higher the debt, the higher are the interest expenses that negatively influence the interest coverage ratio. As the dependent variable is a dummy variable $y$ equal to 1 if interest coverage is less than 1 and 0 if otherwise, then higher debt leads to $y=1$. The influence of current liabilities to current assets and cash flow from operating activity to total debt has the same logic as the influence of leverage, so the sign of this variable should be positive.

Variables that include net income have an impact on EBITDA, which is the numerator of the interest coverage ratio. The dummy for net income, if it was negative over the last two years is equal to 1 and 0 if otherwise. It should have a positive impact as if it is equal to 1 , then interest coverage is lower than 0 , and the dependent dummy is equal to 1 . Therefore, the return on assets and changes in net income also has a positive effect on the interest coverage ratio, but a negative impact on the dependent dummy.

RMJ 16 (1): 37-62 (2018) 
Table 20

Results of hypotheses testing

\begin{tabular}{l|c|c}
\hline Hypothesis (variable) & Expected sign & Estimated sign \\
\hline H1 (Leverage) & + & + \\
\hline H2 $($ Clca $)$ & + & + \\
\hline H3 $($ Nn $)$ & + & Insignificant \\
\hline H4 (Size) & - & - \\
\hline H5 (Wcta) & - & Insignificant \\
\hline H6 $($ ROA $)$ & - & - \\
\hline H7 $($ Ocftl $)$ & - & - \\
\hline H8 $($ Nigrowth) & + & - \\
\hline H9 $($ Bm $)$ & + & + \\
\hline H10 $($ Vol $)$ & + & + \\
\hline H11 $($ Rda $)$ & + & + \\
\hline H11 $($ Rds $)$ & + & + \\
\hline H11 $($ Rde $)$ & + & - \\
\hline H11 $($ Rdcta $)$ & & + \\
\hline
\end{tabular}

The size of company is presented by a natural logarithm of total assets. Logically, the larger the company is, the lower is the likelihood of bankruptcy. Working capital scaled by total assets is expected to be negative, as the numerator of the ratio is estimated as current assets minus current liabilities. Thus, the higher the working capital, the lower are the interest expenses, and the higher is the interest coverage ratio, so the dummy is not equal to 1 .

According to [Zhang, 2015] such market characteristic of a firm as book to market value and stock return volatility has a positive impact upon the probability of distress. This can be explained the following way: if debt rises, then book to market value becomes lower. At the same time, interest expenses go up and the interest coverage ratio fall, and if it is less than 1 , the dependent dummy variable is equal to 1 , which explains the negative relationship.

R\&D expenses have significant impact upon the probability of bankruptcy, and consequently, upon financial distress. Unexpectedly, R\&D indexes have different kinds of effects. R\&D scaled by total assets, sales, and the number of employees depend on the financial results of one year. The influence of these variables is positive. However, research and development capital scaled by total assets demonstrated an adverse impact on the probability of distress, while the forecast was positive. The logic here is that R\&D capital includes the sum of investments in innovative projects over the last four years. Over such a long period time, these projects begin to make a profit, so firm's EBITDA rises and boosts the interest coverage ratio. It should be mentioned that the rest of the R\&D indexes demonstrate a positive relationship, but they do not include prior periods' expenses upon such projects.

A strong positive relationship was found with the financial results of the previous two years. Intuitively, it is clear that if a firm was not in distress over the last two years, it will not be in a state of distress this year, and vice versa. Besides, the results of post crisis periods demonstrate a positive impact upon the probability of financial distress. 
Although most companies from the sample are from the US, they operate in many other countries, where crisis inflicted economic damage not in 2007, but at a later date.

Some firms showed unexpected profits, i.e., their indirect distress costs became "benefits". However, considering the fact that the sample includes massive holdings that invest a great deal of money and assets in innovations and act as leaders on the market, such a result was predictable.

Overall, the total financial distress costs in absolute and relative terms show that they cannot be ignored when making financial decisions, especially at those companies investing in research and development projects. The present paper proposes two models: those for evaluation of direct and indirect costs in the innovative companies. In future research, these models can be expanded with new variables in order to obtain more accurate results.

The following recommendations are suggested for future research:
1. It is necessary to determine the influence of other sets of determinants on the probability of financial distress.

2. Unexpected financial distress costs also should be checked for effects arising from other factors.

3. Another index that characterizes the innovative firms should be developed.

4. The present sample includes large holdings. We recommend that small and medium firms should be analyzed in the future.

5. Furthermore, we suggest comparing financial distress costs and tax benefits in order to find some trade-off values between these variables, and therefore determine the target value of companies. The current paper could be useful for companies that must make a decision concerning investments in research and development projects. It is also helpful for the government, especially the tax authorities, which might regulate innovative companies through tax breaks. Finally, researchers can use this paper as a basis for further investigation.

\section{Appendix}

\section{VIF DATA}

\begin{tabular}{l|c|c||l|c|c}
\hline Variable & VIF & $\mathbf{1} /$ VIF & Variable & VIF & $\mathbf{1}$ VIF \\
\hline Wcta & 4.90 & 0.203924 & Size & 1.94 & 0.516148 \\
\hline Clca & 4.20 & 0.238017 & ROA & 1.91 & 0.523995 \\
\hline Rda & 4.11 & 0.243115 & Bm & 1.69 & 0.591086 \\
\hline Rde & 2.62 & 0.381736 & Nn & 1.43 & 0.699973 \\
\hline Rdcta & 2.61 & 0.383143 & Vol & 1.27 & 0.789283 \\
\hline Rds & 2.48 & 0.403303 & Nigrowth & 1.26 & 0.796759 \\
\hline Leverage & 2.39 & 0.417625 & Ocftl & 1.04 & 0.961825 \\
\hline Tdta & 2.37 & 0.422535 & Mean VIF & 2.41 & \\
\hline
\end{tabular}

\section{REFERENCES}

Altman E. I. 1968. Financial ratios, discriminant analysis and the prediction of corporate bankruptcy. Journal of Finance 23 (4): 589-609.
Altman E.I. 1984. A further empirical investigation of the bankruptcy cost question. Journal of Finance 39 (4): 10671089. 
Andrade G., Kaplan S. N. 1998. How costly is financial (not economic) distress? Evidence from highly leveraged transactions that became distressed. Journal of Finance 53 (5): 1443-1493.

Bhabra G. S., Yao Y. 2011. Is bankruptcy costly? Recent evidence on the magnitude and determinants of indirect bankruptcy costs. Journal of Applied Finance \& Banking 1 (2): 39-68.

Bris A., Welch I., Zhu N. 2006. The costs of bankruptcy: Chapter 7 liquidation versus Chapter 11 reorganization. Journal of $\mathrm{Fi}$ nance 61 (3): 1253-1303.

Bulot N., Salamudin N., Abdoh W. M. 2014. The size and determinants of indirect $\mathrm{fi}$ nancial distress costs. GSTF Journal on Business Review (GBR) 3 (4): 8-17.

Bulot N., Salamudin N., Aziz R. 2017. The size of indirect financial distress costs: Which variable is reliably important? Journal Intelek 12 (1): 12-20.

Charalambakis E., Garrett I. 2016. On the prediction of financial distress in developed and emerging markets: Does the choice of accounting and market information matter? A comparison of UK and Indian Firms. Review of Quantitative Finance and Accounting 47 (1): 1-28.

Chen J., Marshall B., Zhang J., Ganesh S. 2006. Financial distress prediction in China. Review of Pacific Basin Financial Markets and Policies 9 (2): 317-336.

Fedorova E. A., Gilenko E. V., Dovzhenko S.E. 2013. Models for bankruptcy forecasting: Case study of Russian enterprises. Studies on Russian Economic Development 24 (2): 159-164.

Ho C.-Y., McCarthy P., Yang Y., Ye X. 2013. Bankruptcy in the pulp and paper industry: Market's reaction and prediction. $\mathrm{Em}$ pirical Economics 45 (3): 1205-1232.

Hortaçsu A., Matvos G., Syverson C., Venkataraman S. 2013. Indirect costs of financial distress in durable goods industries: The case of auto manufacturers. Review of Financial Studies 26 (5): 1248-1290.

Jones S., Hensher D. A. 2004. Predicting firm financial distress: A mixed logit model. $A c$ counting Review 79 (4): 1011-1038.
Kwansa F. A., Cho M.H. 1995. Bankruptcy cost and capital structure: The significance of indirect cost. International Journal of Hospitality Management 14 (3/4): 339-350.

Laitinen E.K., Suvas A. 2016. Financial distress prediction in an international context: Moderating effects of Hofstede's original cultural dimensions. Journal of Behavioral and Experimental Finance 9: 98-118.

LoPucki L. M., Doherty J. W. 2004. The determinants of professional fees in large bankruptcy reorganization cases. Journal of Empirical Legal Studies 1 (1): 111-141.

Makeeva E., Bakurova A. 2012. Forecasting bankruptcy oil and gas companies using neural networks. Journal of Corporate Finance Research (3): 22-30. (In Russian)

Mansi S., Maxwell W.F., Zhang A. 2012. Bankruptcy prediction models and the cost of debt. Journal of Fixed Income 21 (4): 25-42.

Ohlson J.A. 1980. Financial ratios and the probabilistic prediction of bankruptcy. Journal of Accounting Research 18 (1): 109-131.

Opler T.C., Titman S. 1994. Financial distress and corporate performance. Journal of Finance 49 (3): 1015-1040.

Pham T., Chow D. 1989. Some estimated of direct and indirect bankruptcy costs in Australia: September 1978-May 1983. Australian Journal of Management 14 (1): 75-95.

Thorburn K.S. 2000. Bankruptcy auctions: Costs, debt recovery, and firm survival. Journal of Financial Economics 58 (3): 337-368.

Warner J.B. 1977. Bankruptcy costs: Some evidence. Journal of Finance 32 (2): 337347.

Weiss L.A. 1990. Bankruptcy resolution: Direct costs and violation of priority of claims. Journal of Financial Economics 27 (2): 285-314.

Wijantini W. 2007. The indirect costs of financial distress in Indonesia. Gadjah $M a-$ da International Journal of Business 9 (2): $157-186$.

Zhang W. 2015. R\&D investment and distress risk. Journal of Empirical Finance 32 (C): 94-114.

Zhdanov V.Y., Afanasyeva O.A. 2011. Models of bankruptcy risk for companies of aircraft industry. Journal of Corporate Finance Research (4): 77-89. (In Russian) 
The study was implemented in the framework of the Basic Research Program at the National ResearchUniversity Higher School of Economics (HSE) in 2017 ("The empirical analysis of corporate financial decisions of innovative companies under conditions of the global transformation to an innovative type of economy").

For citation: Makeeva E. Y., Khugaeva M.O. 2018. Evaluation of financial distress costs of innovative companies. Russian Management Journal 16 (1): 37-62. https://doi.org/10.21638/11701/ spbu18.2018.102

Initial Submission: November 25, 2017

Final Version Accepted: March 20, 2018

\section{Оценка издержек финансовой неустойчивости в инновационных колпаниях}

\section{Е. Ю. Макеева}

Доцент, Национальный исследовательский университет «Высшая школа экономики», Москва, Россия

E-mail: len-makeeva@yandex.ru

\section{М.О.Хугаева}

Аспирант, Финансовый университет при Правительстве РФ, Москва, Россия

E-mail: margokhugaeva@mail.ru

В течение последних десятилетий инвестиции в НИОКР существенно возросли. Многие исследователи подтверждают положительную связь между расходами на НИОКР и стоимостью компании. Однако инвестиции в инновации характеризуются высокой степенью неопределенности. Кроме того, инновационные проекты начинают приносить доходы, как правило, в долгосрочном периоде. Эти факторы значительно увеличивают вероятность финансовой неустойчивости компании. Поэтому целью данной работы является оценка издержек финансовой неустойчивости в фирмах, которые инвестируют в НИОКР. В работе проводится анализ финансово-экономических показателей 389 инновационных компаний с 2006 по 2015 г. Анализ основан на оценке прямых и косвенных издержек финансовой неустойчивости фирм. Прямые издержки оцениваются с помощью использования панельной логистической регрессии, а косвенные - как упущенная прибыль или непредвиденный доход в сравнении с отраслевыми показателями. В результате анализа подтверждается связь между расходами на НИОКР и финансовой неустойчивостью компаний. Анализ показывает, что издержки финансовой неустойчивости инновационных фирм составляют $7,95 \%$ от величины общих активов, или в среднем $11,78 \%$ стоимости компании.

Ключевые слова: издержки финансовой неустойчивости, банкротство, инновационные компании, панельная логистическая регрессия.

JEL: G32, G33.

В данной работе использованы результаты проекта «Эмпирический анализ корпоративных финансовых решений инновационных компаний в условиях глобальной трансформации экономики в инновационный тип» Программы фундаментальных исследований НИУ ВШЭ в 2017 г.

$$
\begin{array}{r}
\text { https://doi.org/10.21638/11701/spbu18.2018.102 } \\
\text { Статья поступила в редакиию } \\
25 \text { ноября } 2017 \text { г. } \\
\text { Принята к публкации } \\
20 \text { марта } 2018 \text { г. }
\end{array}
$$

RMJ 16 (1): 37-62 (2018) 